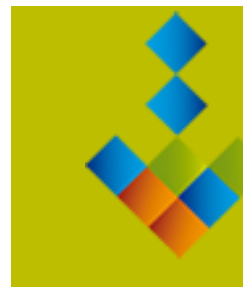

\title{
RITPU|IJTHE
}

ritpu.org | ijthe.org

Revue internationale des technologies en pédagogie universitaire International Journal of Technologies in Higher Education

\section{A pre-post study to assess the impact of an information-problem solving intervention on university students' perceptions and self-efficacy towards search engines}

Interventions portant sur la résolution de problèmes en contexte de recherche d'information : quels impacts sur les perceptions d'auto-efficacité d'étudiants universitaires?

https://doi.org/10.18162/ritpu-2019-v16n1-05
Marioleni PARISSI University of Patras, Greece parisima@upatras.gr

Vassilis KOMIS University of Patras, Greece komis@upatras.gr

Konstantinos LAVIDAS University of Patras, Greece lavidas@upatras.gr

Gabriel DUMOUCHEL Université du Québec à Chicoutimi gabriel_dumouchel@uqac.ca

Thierry KARSENTI

Université de Montréal thierry.karsenti@umontreal.ca

\begin{abstract}
This study investigates the changes in university students' perceptions towards the use of Web search engines after their exposure to a teaching intervention centered on the information problem-solving process. A total of 138 students of the Department of Educational Sciences and Early Childhood Education of the University of Patras were surveyed to measure perceived ease of use and usefulness of search engines and search engine self-efficacy. A questionnaire, part of which was based on the Technology Acceptance Model, was developed and distributed to respondents, both before and after the course, to measure their perceptions. The results revealed statistically significant improvement for the ease of use and usefulness of search engines, as well as for search engine self-efficacy.
\end{abstract}

\section{Keywords}

Information literacy, Big6 model, information problem solving, search engine, self-efficacy of web information searching

\section{Résumé}

Cette étude examine l'évolution des perceptions des étudiants universitaires quant à l'utilisation des moteurs de recherche après leur exposition à une intervention pédagogique centrée sur le 
processus de résolution de problèmes informationnels. Au total, 138 étudiants du Département des Sciences de l'Education - Section Préscolaire de l'Université de Patras ont été interrogés pour mesurer leur perception de l'utilité et de la facilité d'utilisation des moteurs de recherche. Un questionnaire, basé en partie sur le modèle d'acceptation technologique TAM, a été élaboré et distribué aux répondants avant et après le cours afin de mesurer leurs perceptions. Les résultats ont révélé une amélioration statistiquement significative de la facilité d'utilisation et de l'utilité des moteurs de recherche, ainsi que pour leur sentiment d'auto-efficacité à l'égard des moteurs de recherche.

\section{Mots-clés}

Littératie informationnelle, modèle «Big6», résolution de problèmes informationnels, moteur de recherche, auto-efficacité de la recherche d'information sur le web

\section{Introduction}

In the twenty-first century, the definition of literacy has increasingly reflected the ability to use technology for gathering and communicating information (Pilgrim \& Martinez, 2013). Information and technology literacy consists of a set of basic skills that an individual should possess today. Not only does the modern citizen need to be able to use computers, but he should also be able to apply computer skills to real situations and needs (Lavidas, Komis, \& Voulgari, 2017). Computer skills are required in order to search for information that constitutes or supports solutions to simple or more complex problems (Mawby, Foster, \& Ellis, 2015). These problems are called information problems (Walraven, Brand-Gruwel, \& Boshuizen, 2008), since they require information to be found and used. One of the many kinds of "information retrieval systems" is the search engine, an essential tool for finding useful information on the World Wide Web (Web). According to Sterling (2017), Google is by far the most popular search engine and is used all over the world, with hundreds of millions of search queries every single day.

In the past few years, information systems have come to dominate modern life, whether people are fully aware of their use or not. Different factors seem to affect their degree of use. Perceived ease of use (PEOU) and usefulness (PU) as well as self-efficacy have been widely credited with influencing the behavioural intention of users to use an information system (Almaiah, 2018; Davis, 1989). According to Surendran (2012), PEOU and PU are major factors in computer use behaviour based on the Technology Acceptance Model (TAM), developed by Davis (1989). Moreover, Rose, and Fogarty's (2006) study found that self-efficacy is a significant predictor of PEOU and PU. Self-efficacy in the field of information seeking studies and, more specifically, in Wilson's general model of information behaviour (1997) is conceived as one of the activating mechanisms of information seeking behaviour.

At the same time, several studies highlight the importance of IPS instruction in helping students perform effective searches on the Web (Brand-Gruwel, Wopereis \& Walraven, 2009; Wopereis et al., 2008). A review of the literature reveals that different information problem-solving models exist that can be used to teach students the information problem-solving (IPS) process (BrandGruwel et al., 2009). The Information Search Process (ISP) model (Kuhlthau, 2004) and the Big Six Skills Model (Eisenberg \& Berkowitz, 1990) are considered to be two of the most widely adopted process models in the field of information literacy (Gross, Armstrong \& Latham, 2012). 
Thus, this article studies the effects of a teaching intervention, based on the Big6 model, on university students' perceptions and self-efficacy regarding the use of search engines. Big6 (http://thebig6.org) is a process model for information problem-solving. Developed in 1987 by Mike Eisenberg and Bob Berkowitz (2011), it is a well-known approach to teaching information and technology skills. It integrates information search tools with information technology tools in a systematic process to find, use, apply, and evaluate information for specific needs and tasks.

\section{Background}

During the past few decades, research in the field of Information Systems has focused on understanding the effect of perceived self-efficacy, ease of use and usefulness on behaviours of information system users (John, 2013; Rose \& Fogarty, 2006). The TAM model (Davis, 1989; Davis, Bagozzi, \& Warshaw, 1989) has been widely applied in studies conducted to explain the acceptance behaviour of individuals using information technology and information systems (Surendran, 2012). In this model, the construct of "perceived usefulness" (PU) is defined as a user's subjective perception of the extent to which a computer system will aid work performance, while "perceived ease of use" (PEOU) refers to the extent to which the user expects a computer system or software to be easy to learn and use. The results of AmoakoGyampah's study (2007) revealed that PEOU influences users' behaviours and system usage, either directly or indirectly, through the system's usefulness. Amoako-Gyampah also asserts that the easier it is to use a technology, the greater the benefits that can be expected from it. On the other hand, PU is related to individual impacts, such as improved individual productivity and performance (Seddon, 1997).

Social Cognitive Theory (SCT) declares that beliefs about outcomes are insufficient if individuals have doubts regarding their capabilities to undertake behaviours (Bandura, 1977). Bandura asserts that self-efficacy, in combination with outcome expectations, must be examined. The term "self-efficacy" refers to people's beliefs about their capabilities to produce desired effects by their own actions. Bandura (1977) reports that self-efficacy is a major determinant of people's choice of activities, how much effort they will expend and how long they will sustain effort in dealing with stressful situations. In their study, Aharony and Gazit (2018) underline the importance of increasing students' intrinsic motivation in order to improve their information literacy self-efficacy that may help them in the academy, as well as in other aspects of their life in the future. Even though today's students are 'digital natives' and regularly use computers, some feel stressed when they have to handle vast amounts of information. Based on the results of Adalier and Serin's study (2012), the more self-efficacy a person has, the higher the information searching performance level can be expected. In their study, Keshavarz, Esmaeili Givi, and Vafaeian (2016) have also noted that the users' sense of self- efficacy plays an important role in successful information seeking. Similarly, while a study conducted (Parissis, Tselios, \& Komis, 2010) to investigate the relationship between the participants' search engine self-efficacy and the effectiveness of the expressed search actions, it was found that student's self-efficacy is related to their expressed task performance.

Educational interventions can enhance students' sense of self-efficacy in using search engines (Cordes, 2014; Van Dinther, Dochy, \& Segers, 2011; Venkatesh \& Bala, 2008). Students with procedural knowledge on how to use search engines will have more information on how easy or difficult the system is to use (Venkatesh \& Bala, 2008). In addition, perceived ease of use and perceived usefulness seem to have a positive association with variables for involvement and 
control (Cordes, 2014). Cordes's findings also reveal that when users have a stronger sense of control when using a search tool in terms of system feedback and interactivity, they find it easier to use and may spend less time performing searches. As a result, this permitted them to become more involved in developing effective searches, leading to better results and stronger perceptions of usefulness. Moreover, a review by Van Dinther et al. (2011) shows that it is possible to influence students' self-efficacy through an educational program. More specifically, eighty percent of the intervention studies across several domains revealed a significant correlation between an intervention program and students' self-efficacy. As for the information systems in particular, an educational program can help individuals familiarize themselves with the systems' characteristics and applications.

A study conducted shows that students who have followed embedded instruction for information problem solving (IPS) regulate the IPS process and judge the information found more often than students who did not receive this instruction (Wopereis et al., 2008). Therefore, today's educational system is required to make individuals capable of solving information problems effectively while using the Internet. In fact, teaching interventions about the information problem-solving process can positively affect perceived ease of use and usefulness as well as self-efficacy regarding the use of Internet search tools. Venkatesh and Bala (2008), confirm that teaching interventions that help users obtain accurate perceptions of the characteristics and benefits of a system are of crucial importance during the initial phase of learning the system. Moreover, they are deemed essential for helping to minimize initial resistance to a new system and for helping to provide users with a realistic preview of it, which will help them develop an accurate perception of the features of a specific system and how it can help them accomplish their task. Y. H. Chen and Chengalur-Smith's (2015) research outcomes regarding the information literacy instruction used as an intervention in their work found that training could shape user beliefs, foster favorable attitudes, and facilitate use. The above factors could, in turn, influence the behavioural intentions of students to use Web search tools. Web search tools are used to facilitate the process of searching the desired piece of information and are therefore included in information problem-solving models.

One of the prevailing models for teaching students how to solve an information problem is the Big6, due to its simplicity and its user-friendly approach to what are often extremely complex tasks (Thomas, Crow, \& Franklin, 2011). In the following section, we argue why our study will use the Big6 as a basis to teach students how to solve information problems with the aid of Web search tools.

\subsection{The Big6 Teaching Model for the Information Problem-Solving Process}

A strong body of anecdotal research highlights the usefulness of the Big6 model, but only a limited number of studies look into what makes it an effective model and how it affects problem solving (L. C. Chen, Chen, \& Ma, 2017). Several information problem-solving models exist for the IPS process, but the Big6 model helps students develop the skills and understanding that are necessary to find, process and use information effectively (Gross et al., 2012). As SantanaArroyo (2013) notes, the Big6 model is an information literacy curriculum, an information problem-solving process, and a set of skills that provides a strategy for meeting information needs effectively and efficiently. By learning through this curriculum, students should be able to realize what they need to accomplish, decide whether a computer will help them to do so, and then be able to use the computer as part of the process of accomplishing their task (Eisenberg \& Johnson, 2002). 
The specific model is comprised of six major stages, each one containing two sub-stages, thus covering the full scope of the information problem-solving process (see Table 1). The models' significance lies in the fact that it is applicable to both professional and personal life. According to one of its authors (Eisenberg, 2008), the Big6 differs from other models in that it provides a broad-based, logical skill set that can be used as a structure for developing curriculums involving distinct problem-solving skills. Eisenberg (2008) declares that the Big6 model doesn't teach "isolated" computer skills; it teaches "integrated" information and technology skills. Several studies suggest that the Big6 model can be employed to teach how to use search engines (Foo et al., 2014; Santana-Arroyo, 2013). By applying the specific model, search engine users will understand how to select keywords and how to use Booleans operators and their possible combinations in order to perform a specialized query in a search engine to generate the best results.

\section{Table 1}

The Big6 Model (Eisenberg \& Berkowitz , 1990)

\begin{tabular}{|c|c|}
\hline Stage of the Big6 model & Sub-step of the stage \\
\hline 1. Task definition & $\begin{array}{l}\text { 1.1 Define the information problem } \\
\text { 1.2 Identify information needed }\end{array}$ \\
\hline 2. Information seeking strategies & $\begin{array}{l}\text { 2.1 Determine all possible sources } \\
\text { 2.2 Select the best sources }\end{array}$ \\
\hline 3. Location and access & $\begin{array}{l}\text { 3.1 Locate sources (intellectually and physically) } \\
\text { 3.2 Find information within sources }\end{array}$ \\
\hline 4. Use of information & $\begin{array}{l}\text { 4.1 Engage (e.g., hear, read, view) } \\
\text { 4.2 Extract relevant information }\end{array}$ \\
\hline 5. Synthesize & $\begin{array}{l}\text { 5.1 Organize from multiple sources } \\
\text { 5.2 Present the information }\end{array}$ \\
\hline 6. Evaluation & $\begin{array}{l}\text { 6.1 Judge the product (effectiveness) } \\
6.2 \text { Judge the process (efficiency) }\end{array}$ \\
\hline
\end{tabular}

The present study attempts to explore the extent to which a teaching intervention based on the Big6 model $^{1}$ can influence university students' perceptions and self-efficacy towards the use of search engines.

\subsection{Research Questions}

The goal of this study is to investigate the impact of a teaching intervention based on the Big6 model regarding the IPS process and Internet search tools on students' perceptions and selfefficacy regarding search engine use. More specifically, through this study, we attempt to answer the following research questions:

Could a student's teaching intervention focusing on the use of Web search engines to solve information problems enhance:

- students' perceptions regarding the ease of use of search engines?

1. The main sources we used for the development of the teaching intervention instructions are the Big6 website (http://thebig6.org), Murrray (2015), and Eisenberg \& Berkowitz (2007). 
- students' perceptions regarding the usefulness of search engines?

- students' self-efficacy concerning the use of search engines?

\section{Methodology}

\subsection{Research Design}

This study made use of a quasi-experimental design to investigate whether a didactic intervention on the IPS process and Web search tools has an effect on university students' perceptions regarding the use search engines. This research design was suitable for determining whether there is a causal relationship between the independent and the dependent variables. The independent variable was the didactic intervention and the dependent variables were students' perceived self-efficacy, usefulness and ease of use of search engines.

\subsection{Participants}

The research was conducted in the context of a compulsory course at the University of Patras with a sample of 138 university students (mean age of 20.2 years; $\mathrm{SD}=3.2$ years). The sample consisted of 5 male students and 133 female students. The course "ICT in Education" is held in the second semester of the second year at the Department of Educational Sciences and Early Childhood Education at the University of Patras in Greece. Therefore, the majority of the participants (126) were second-year students. The sample also included ten third-year students, one fourth-year student and one graduate student. The students, after being informed about the objectives of the study and assured that the research data would be kept confidential, were asked if they were willing to participate in the research study. All of the students agreed to participate in the study.

\subsection{Research Procedure}

The research was conducted at the Department of Educational Sciences and Early Childhood Education of the University of Patras, within the compulsory course "ICT in Education", from February to June 2011. This course aims to help students become familiar with the main approaches to the introduction and integration of ICT in the educational process as well as the main models of ICT introduction in education. It also helps students develop basic skills in using current educational computer applications. A weekly three-hour lecture is given by the professor for 13 consecutive weeks, while two teaching assistants are in charge of the compulsory laboratory component (13 two-hour lessons). 138 undergraduates had enrolled in the course; their attendance at the laboratory sessions was mandatory for passing the course. These students were divided into seven groups of 20 students each, to match the number of workstations in the lab. The goal of this study was to determine participants' perceptions regarding the perceived self-efficacy, usefulness and ease of use of search engines before and after an appropriate intervention.

\subsubsection{Pre-Test Stage}

During this stage, the 138 students who attended the course were asked to complete a survey during the first two-hour laboratory session. The survey included questions related to the objectives of this study. Participants were provided with a link to the online data collection 
platform SurveyMonkey, which gave them access to the survey. It took an average of 15 minutes to complete the questionnaire.

\subsubsection{The Intervention: IPS Instruction}

Following the pre-test, the 138 students who participated in this research received a two-hour intervention during the second two-hour laboratory session. The didactic intervention focused on increasing awareness of the IPS process and teaching students how to seek information using Web search engines.

\subsubsection{Post-Test}

The purpose of this stage was to determine the effect of the didactic intervention on the participants' perceived self-efficacy, ease of use and usefulness regarding the use of search engines. Consequently, all participants (138 students) were asked to answer the same questionnaire (post-survey) during the last laboratory session (13th session).

\subsection{Teaching Intervention}

Research in higher education has revealed that university students depend on the Internet to look for information to accomplish both academic and non-academic tasks, and that they do so mainly by using general-purpose search engines such as Google (Salehi, Du, \& Ashman, 2018). Studies on the use of various search engines reveal that people of all ages have difficulties using them. For example, seniors seem to have difficulty in finding the information they want about search engines (Morrison, 2015). Aula, Khan, and Guan (2010) found that as task difficulty increases, users issue more queries and are more likely to visit more Web pages and spend more time on search engine result pages. Moreover, Walraven et al. (2008) show that children, teenagers and adults have difficulties specifying search terms, judging search results, sources and information. Their study also notes problems in the regulation of the process. Studies conducted at the University of Patras have led to similar findings. For example, Ntoulas, Stamou, Tzagarakis, and Christodoulakis (2001) reported that while users of search engines tend to use the functions of the engines they already know in order to find the information they want from the Web, they are not familiar with Boolean operators or search facilities that support them. The results of another study (Parissis et al., 2010) conducted to investigate university students' information search strategies showed that most students used multiple keywords to find the required information and made limited use of logical operators and other logical expressions. These findings illustrated that these students have little knowledge of how to use search engines while seeking specific information. For this reason, a teaching intervention was developed to teach students how to use search engines more effectively to solve information problems. The instructional design of the intervention was based on the Big6 model of Eisenberg and Berkowitz (1990) and the Problem-Solving Approach developed by University of Patras researchers (Lavidas, Komis, \& Gialamas, 2013; Lavidas et al., 2017).

Hence, as mentioned above, a teaching intervention concerning the information problem solving process, the Internet and its basic applications was conducted during the second compulsory laboratory session of the course "ICT in Education," held in the spring semester of the academic year 2010-2011. The intervention focused on search techniques and strategic approaches to information retrieval (Notess, 2006). The intervention was divided into two parts. The first part focused on clarifying the concept of information problems and on the IPS process. The main 6 
steps and subcategories of the IPS process (Eisenberg \& Berkowitz, 1990) were clearly presented in this part. The second part consisted of the description of basic Web search tools (directories, portals, search engines) and information-searching strategies on the Web. Specifically, during the first part of the intervention after referring to the definition of the term "information problems," students were asked to think of examples of information problems they encounter in their daily lives. The first part of the intervention was completed when several problems based on everyday information needs were mentioned and it was perceived that students had a satisfactory understanding of the term. The second part covered ways to approach and solve examples of information problems containing suitable cognitive conflicts in order to help students acquire more in-depth Internet skills for the purpose of solving similar problems. As claimed by de Grave et al. (1996), cognitive conflicts lead to conceptual changes. Accordingly, after a detailed presentation of the Big6 model and its stages by the teaching assistant, all students in each laboratory group (18 to 20 students in each session) had to collaborate to solve, step by step, several simple to more complex information problems of everyday life. For example, they were asked to find out which movies were playing in theaters that day and how much it cost to see them. In order to solve these problems they had to apply the steps of the model to each of the different information problems. For example, they first had to define the problem they had at hand and make the type of information needed as specific as possible (Lavidas et al., 2013). Subsequently, they had to determine all possible information sources and decide on the best one. In all cases, the Internet was considered the most suitable tool because of its quick access and the fact that it instantly gives a range of results with possible answers. Third, after realizing that search engines were the most suitable tools to help them find the desired information, they had to develop a list of keywords associated with the topic and refine them throughout the research process. They had to write down the topic, extract important words from that topic and find synonyms or related words. They then had to decide which of the search results could give them an answer based on the summary Google displays for each result. They extracted relevant information, discussed together the different answers given and ended up choosing the most appropriate one. Finally, they completed each solving procedure by judging the results and the series of steps followed. This procedure was repeated for a number of examples that had some interest for the students.

\subsection{Research Instruments}

The same survey instrument was used in the pre-and post-test to collect data from study participants. The survey was composed of four parts: demographic information, perceptions towards ease of use of search engines (PEOU), perceptions towards usefulness of search engines (PU) and self-efficacy towards the use of search engines.

Part one of the survey instrument asked for general demographic information (e.g. age, gender, education level, presence of a computer in their home, Internet access at home, length of time of Internet use) of the survey participants.

Parts Two and Three of the survey instrument included two components referring to respondents' perceptions of ease of use and usefulness of search engines. The two components were developed based on the Technology Acceptance Model (TAM). Two of the five dimensions of the TAM model were adapted: perceived ease of use (PEOU) and perceived usefulness (PU). Both the PEOU and PU scales consisted of six items. All questions were measured on a 7-point Likert scale $(1=$ very likely to $7=$ very unlikely). The study required translating the survey 
instrument into Greek: first, two translators converted the scale statements from English to Greek, then two other translators converted the scale statements back to English. All four translators worked independently so as not to be influenced by each other. After that, the two English versions of the questionnaire were compared to the original English scales.

The Cronbach's alpha for the 6 items consisting of the PEOU subscale was $\alpha=0.879$ for the pretest and $\alpha=0.901$ for the post-test survey, suggesting a good reliability for the subscales. The Cronbach's alpha for the 6 items of the PU subscale was $\alpha=.932$ and $\alpha=0.912$ respectively, suggesting they also have good reliability (Field, 2013).

Part four consisted of a component of perceived self-efficacy in using advanced Google search strategies. The term "perceived self-efficacy" refers to an identified level and strength of selfefficacy, in which strength is measured by the degree of certainty that one can perform a specific task (Bronstein, 2014). According to Kurbanoglu, Akkoyunlu, and Umay (2016), self-efficacy should be measured directly by the use of self-report scales. Bronstein (2014) declares that these scales consist of Likert items asking respondents to rate the strength of their perceptions of their abilities to perform specific behaviours successfully. Therefore, the self-efficacy scale employed in the current research is self-constructed (Bandura, 2006). The self efficacy scale, a 17-item inventory that measures respondents' beliefs about their abilities to implement advanced Google search strategies, is based on Bandura's concept of self- efficacy (Bandura, 2006). Students asked to rate how confident they are could use Google's advanced search features by selecting a number on a 7-point scale, from " $1=$ not at all capable" to "7 = completely capable". The Likert items used were developed based on information found on Google's Advanced Search page, launched in the year 2010. The search features on this page that can make a search easier and more efficient were specifically included in the survey. Cronbach's alpha reliability for the search engine self-efficacy scale (17 items) for both the pre- $(\alpha=.906)$ and the post- $(\alpha=.891)$ intervention questionnaires, demonstrated good internal consistency.

The questions/statements of the survey instrument are presented in the tables of the results section of the appendix.

\section{Results}

The quantitative analysis of the collected data was analyzed with SPSS 24 . The data obtained from 138 participants of the study were analyzed using descriptive statistics and paired-samples $t$-tests (Field, 2013). The $p<.05$ standard was used to depict statistical significance throughout the study. A one-tailed test was used because only one direction of change is of interest to us: whether perceptions significantly improved after the intervention. Descriptive statistics were run to analyze the data from the pre-post intervention questionnaire concerning perceived ease of use, usefulness and search engine self-efficacy.

Table 2 shows the results of paired sample $t$-tests comparing the pre- and post-intervention mean values of students' answers to six questionnaire items related to their perceptions of ease of use of search engines. The mean values of the students' answers in the pre-intervention questionnaire range from to 5.49 to 5.97 while the mean values of their answers in the post-intervention questionnaire range from 5.77 to 6.16. Overall, the mean values of students' answers for all six items and the overall score of perceived ease of use point to a statistically significant improvement in students' perceptions. 
Table 2

Measurements for Perceived Ease of Use (PEOU): Pre-and Post-Intervention ( $N=138)$

\begin{tabular}{|c|c|c|c|c|c|c|c|c|}
\hline \multirow[t]{2}{*}{ Item code } & \multirow[t]{2}{*}{ Perceived ease of use } & \multicolumn{2}{|c|}{$\begin{array}{l}\text { Pre- } \\
\text { intervention }\end{array}$} & \multicolumn{2}{|c|}{$\begin{array}{l}\text { Post- } \\
\text { intervention }\end{array}$} & \multirow[b]{2}{*}{$t$} & \multirow[b]{2}{*}{ df } & \multirow[b]{2}{*}{$p$} \\
\hline & & $M$ & $S D$ & $M$ & $S D$ & & & \\
\hline PEOU1 & $\begin{array}{l}\text { Learning to operate search engines is } \\
\text { easy for me. }\end{array}$ & 5.96 & 0.86 & 6.16 & 0.77 & 2.61 & 137 & .010 \\
\hline PEOU2 & $\begin{array}{l}\text { I find search engines to be flexible to } \\
\text { interact with. }\end{array}$ & 5.88 & 0.86 & 6.16 & 0.78 & 3.47 & 137 & .001 \\
\hline PEOU3 & $\begin{array}{l}\text { It is easy for me to become skillful at } \\
\text { using search engines. }\end{array}$ & 5.87 & 0.89 & 6.07 & 0.84 & 2.29 & 137 & .023 \\
\hline PEOU4 & $\begin{array}{l}\text { I find it easy to get search engines to } \\
\text { do what I want to do. }\end{array}$ & 5.49 & 1.12 & 5.77 & 0.97 & 2.68 & 137 & .008 \\
\hline PEOU5 & I find search engines easy to use. & 5.82 & 0.94 & 6.11 & 0.82 & 3.38 & 137 & .001 \\
\hline PEOU6 & $\begin{array}{l}\text { My interaction with search engines } \\
\text { is clear and understandable. }\end{array}$ & 5.48 & 1.04 & 5.82 & 0.88 & 3.33 & 137 & .001 \\
\hline \multicolumn{2}{|c|}{ Overall PEOU } & 5.75 & 0.76 & 6.01 & 0.69 & 3.99 & 137 & .000 \\
\hline
\end{tabular}

The estimates of the effect size revealed a medium effect of the teaching intervention, since the obtained values were between $0.2 \leq r<0.32$ (Field, 2013).

Table 3 shows results of measurements before and after the teaching intervention relating to students' perceptions of usefulness of search engines. The mean values of the pre-intervention questionnaire range from 6.09 to 6.50 , while the mean values of the post-intervention questionnaire range from 6.36 to 6.68. The mean values of answers to the six items as well as the overall scale score of perceived usefulness given by the students in the post-intervention questionnaire are significantly higher compared to the values of answers in the preintervention questionnaire.

Table 3

Measurements for Perceived Usefulness (PU): Pre- and Post-Intervention ( $N=138)$

\begin{tabular}{|c|c|c|c|c|c|c|c|c|}
\hline \multirow[t]{2}{*}{$\begin{array}{l}\text { Item } \\
\text { code }\end{array}$} & \multirow[t]{2}{*}{ Perceived usefulness } & \multicolumn{2}{|c|}{$\begin{array}{c}\text { Pre- } \\
\text { intervention }\end{array}$} & \multicolumn{2}{|c|}{$\begin{array}{c}\text { Post- } \\
\text { intervention }\end{array}$} & \multirow[b]{2}{*}{$t$} & \multirow[b]{2}{*}{ df } & \multirow[b]{2}{*}{$p$} \\
\hline & & $M$ & $S D$ & $M$ & $S D$ & & & \\
\hline PU1 & $\begin{array}{l}\text { Using search engines in my job would increase } \\
\text { my productivity. }\end{array}$ & 6.20 & 1.03 & 6.45 & 0.72 & 2.73 & 137 & .007 \\
\hline PU2 & $\begin{array}{l}\text { Using search engines in my job would enable } \\
\text { me to accomplish tasks more quickly. }\end{array}$ & 6.24 & 0.92 & 6.51 & 0.71 & 3.00 & 137 & .003 \\
\hline PU3 & I find search engines useful in my job. & 6.50 & 0.73 & 6.68 & 0.54 & 2.78 & 137 & .006 \\
\hline PU4 & $\begin{array}{l}\text { Using search engines would enhance my } \\
\text { effectiveness on the job. }\end{array}$ & 6.09 & 0.99 & 6.36 & 0.82 & 2.87 & 137 & .005 \\
\hline PU5 & $\begin{array}{l}\text { Using search engines would improve my job } \\
\text { performance. }\end{array}$ & 6.14 & 0.92 & 6.48 & 0.78 & 4.07 & 137 & .000 \\
\hline PU6 & $\begin{array}{l}\text { Using search engines would make it easier to } \\
\text { do my job. }\end{array}$ & 6.30 & 0.90 & 6.59 & 0.66 & 3.93 & 137 & .000 \\
\hline \multicolumn{2}{|c|}{ Overall PU } & 6.24 & 0.07 & 6.51 & 0.05 & 3.94 & 137 & .000 \\
\hline
\end{tabular}


The estimates of the effect size revealed a medium effect of the teaching intervention, since the obtained values were between $0.2 \leq r<0.32$ (Field, 2013).

Table 4 shows results of measurements before and after the teaching intervention concerning students' perceived search engine self-efficacy. The mean values of respondents' preintervention answers for the 17 questions regarding the statements about perceived search engine self-efficacy ranged from 2.92 to 5.20. The answer with the highest average score related to respondents' capability to change the language of results pages that are returned by the search engine. The question with the lowest average answer referred to determining the time elapsed since the last page update the search engine will display. The mean values of the answers the students gave at the post-intervention questionnaire ranged from 3.64 to 5.48.

\section{Table 4}

Measurements for Perceived Search Engine Self-Efficacy: Pre and Post Intervention ( $N=138$

\begin{tabular}{|c|c|c|c|c|c|c|c|c|}
\hline \multirow[t]{2}{*}{ Item } & \multirow[t]{2}{*}{$\begin{array}{l}\text { Advanced Google } \\
\text { search strategies }\end{array}$} & \multicolumn{2}{|c|}{$\begin{array}{c}\text { Pre- } \\
\text { Intervention }\end{array}$} & \multicolumn{2}{|c|}{$\begin{array}{c}\text { Post- } \\
\text { Intervention }\end{array}$} & \multirow[b]{2}{*}{$t$} & \multirow[b]{2}{*}{ df } & \multirow[b]{2}{*}{$p$} \\
\hline & & $M$ & $S D$ & $M$ & $S D$ & & & \\
\hline 1 & Find exact phrase & 4.91 & 1.23 & 5.15 & 1.13 & 3.76 & 137 & .000 \\
\hline 2 & Search within a website & 4.96 & 1.17 & 5.31 & .86 & 3.68 & 137 & .000 \\
\hline 3 & Exclude words & 4.24 & 1.43 & 5.28 & 1.04 & 1.72 & 137 & .088 \\
\hline 4 & $\begin{array}{l}\text { Use the wildcard asterisk }(*) \text { to create searches where } \\
\text { there are unknown characters, multiple spellings or } \\
\text { various endings }\end{array}$ & 3.06 & 1.55 & 3.78 & 1.51 & 2.11 & 137 & .037 \\
\hline 5 & Exact match search on a single word & 4.98 & 1.29 & 5.42 & 1.08 & 4.78 & 137 & .000 \\
\hline 6 & $\begin{array}{l}\text { Search for any one of one or more terms to match }-\mathrm{OR} \\
\text { operator }\end{array}$ & 4.48 & 1.54 & 4.95 & 1.18 & 4.49 & 137 & .000 \\
\hline 7 & Define the number of search results on page & 3.99 & 1.70 & 4.28 & 1.53 & 3.85 & 137 & .000 \\
\hline 8 & Define the language of the search results displayed & 5.20 & 1.48 & 5.48 & 1.19 & 4.70 & 137 & .000 \\
\hline 9 & Choose the file type you want to search & 3.86 & 1.48 & 4.59 & 1.43 & 5.56 & 137 & .000 \\
\hline 10 & $\begin{array}{l}\text { Define the date/time of last update of the websites } \\
\text { displayed }\end{array}$ & 2.92 & 1.48 & 3.64 & 1.46 & 5.40 & 137 & .000 \\
\hline 11 & Search within a specific domain & 3.14 & 1.63 & 3.74 & 1.60 & 4.91 & 137 & .000 \\
\hline 12 & $\begin{array}{l}\text { Define where the term will appear in the webpage-like } \\
\text { title or URL }\end{array}$ & 2.97 & 1.55 & 3.70 & 1.60 & 2.70 & 137 & .008 \\
\hline 13 & Define the geographical location of the search results & 2.96 & 1.73 & 3.85 & 1.58 & 3.65 & 137 & .000 \\
\hline 14 & Search for a range of numbers & 2.93 & 1.80 & 3.80 & 1.67 & 8.36 & 137 & .000 \\
\hline 15 & Activate the safe search filter & 3.08 & 1.69 & 3.91 & 1.63 & 4.58 & 137 & .000 \\
\hline 16 & Find pages with similar content to a site given & 4.65 & 1.43 & 5.08 & 1.28 & 3.29 & 137 & .001 \\
\hline 17 & $\begin{array}{l}\text { Find search results that contain hyperlinks to websites } \\
\text { given }\end{array}$ & 3.74 & 1.64 & 4.34 & 1.47 & 2.07 & 137 & .040 \\
\hline \multicolumn{2}{|r|}{ Overall self-efficacy } & 3.89 & 0.96 & 4.47 & 0.82 & 7.8 & 137 & .000 \\
\hline
\end{tabular}

Analysis of the answers to the final questionnaire also revealed that the question with the lowest evaluation was related to determining the last date and time of the results page, while the 
question with the highest average score related to defining the language of Web pages. Results of the paired samples $t$-test of the pre- and post-intervention measurements showed statistically significant differences for all items of the "perceived self-efficacy" scale as well as overall selfefficacy concerning the use of advanced search engine operations, except the item about the ability to exclude words from search results.

The estimates of the effect size revealed a medium effect of the teaching intervention, since the obtained values were between $0.2 \leq r<0.32$ (Field, 2013).

\section{Discussion}

This research examined the effect of a Big6 teaching intervention on university students' perceptions regarding the use of search engines on (i) perceived ease of use, (ii) perceived usefulness; and (iii) sense of self-efficacy. To reach our research objectives, a statistical analysis of the survey answers was conducted. From the research results, it is strongly evident that the teaching intervention can improve students' perceptions regarding the ease of use and usefulness of search engines. The results displayed show that there are significant changes in the mean average of the indicator of search engine self-efficacy after the teaching intervention, compared to the corresponding mean average of the indicator before the intervention was applied. The statistical analysis showed that the intervention had a positive impact on both students' perceptions and self-efficacy towards Web search engines. The Big6 model used as a framework to teach information problem-solving proved to be effective and supportive for university students. It proved to be a satisfactory intervention for the majority of the students, because their perceptions regarding the ease of use and usefulness as well as their self-efficacy beliefs about their ability to use search engines improved. The Big6 intervention contributed to the enhancement of students' knowledge and understanding of the IPS process and how search engines work. It appears that due to the intervention, search engines became more familiar to participants and, as such, seemed easier to use. This is consistent with Davis and Venkatesh (2004), who argued that in order for an individual to form stable perceptions of ease of use of a system, he ought to have hands-on experience with the system.

DeLone and McLean (2003) also report that an individual performance impact can result when an information system has given the user a better understanding of the decision context or has changed the user's perception of the usefulness of the information system. Venkatesh and Bala (2008) state that the application of interventions during the pre-implementation phase of an information system is of immense importance because it can ensure accurate perceptions of system features and how the system can help them perform a task. They also mention that information-related characteristics of a system will influence the determinant of perceived usefulness, and that the system-related characteristics will influence the determinants of perceived ease of use.

Furthermore, findings show that after students attended the specific course, their overall sense of self-efficacy regarding advanced uses of search engines was improved. A review by Van Dinther et al. (2011) reveals that within higher educational institutions, there is a significant correlation between an intervention program and students' self-efficacy. Programs based on social cognitive theory have a stronger potential to enhance students' self-efficacy. This observation is consistent with our collaboratively structured intervention, as shown above. The university students had to cooperate and apply the six stages of the Big6 model to solve examples of information problems during the teaching intervention. 
In this article we have reported the results of a small case study related to students' perceptions and self-efficacy regarding the use of search engines. We suggest that improvement in university students' perceptions and self-efficacy can have a positive effect on their search strategies and behaviours.

Results from the present study cannot be generalized beyond the present setting. Studies with larger samples should be conducted using both quantitative and qualitative data to reinforce their results. Another limitation of the study, as with many other studies that are based on selfreported behaviour, is that its accuracy is difficult to verify. In addition, it is possible there is a bias as a result of the use of a quasi-experiment for this study. Most notably, a control group should be used for comparison with the experimental group.

Research findings indicate that university students should be taught information literacy concepts as well as how to apply the information problem-solving process and use Internet search tools. Not only higher education institutions, but educational institutions of all levels as well should incorporate teaching interventions in their programs concerning Internet search strategies and the IPS process (Georgas, 2013; Malliari, Togia, Korobili, \& Nitsos, 2014). In this sense, information literacy programs are important for the educational process, but the impact of such programs should also be informed by research that investigates their impact in detail.

\section{References}

Adalier, A., \& Serin, O. (2012). Teacher candidates' information literacy self-efficacy. Tojsat, 2(2), 71-78. Retrieved from http://tojsat.net

Aharony, N., \& Gazit, T. (2018). Students' information literacy self-efficacy: An exploratory study. Journal of Librarianship and Information Science. doi:10.1177/0961000618790312

Almaiah, M. A. (2018). Acceptance and usage of a mobile information system services in University of Jordan. Education and Information Technologies, 23(5), 1873-1895. doi:10.1007/s10639-018-9694-6

Amoako-Gyampah, K. (2007). Perceived usefulness, user involvement and behavioral intention: An empirical study of ERP implementation. Computers in Human Behavior, 23(3), 1232-1248. doi:10.1016/j.chb.2004.12.002

Aula, A., Khan, R. M., \& Guan, Z. (2010). How does search behavior change as search becomes more difficult? In Proceedings of the SIGCHI Conference on Human Factors in Computing Systems (pp. 35-44). New York, US: ACM. doi:10.1145/1753326.1753333 Retrieved from Paul G. Allen School of Computer Science \& Engineering website: http://cs.washington.edu

Bandura, A. (1977). Self-efficacy: Toward a unifying theory of behavioral change. Psychological Review, 84(2), 191-215. doi:10.1037/0033-295X.84.2.191 Retrieved from CiteSeerX: http://citeseerx.ist.psu.edu

Bandura, A. (2006). Guide for constructing self-efficacy scales. In F. Pajares \& T. Urdan (Eds.), Self-efficacy beliefs of adolescents (pp. 307-337). Greenwich, US: Information Age. 
Brand-Gruwel, S., Wopereis, I., \& Walraven, A. (2009). A descriptive model of information problem solving while using Internet. Computers \& Education, 53(4), 1207-1217. doi:10.1016/j.compedu.2009.06.004

Bronstein, J. (2014). The role of perceived self-efficacy in the information seeking behavior of library and information science students. The Journal of Academic Librarianship, 40(2), 101-106. doi:10.1016/j.acalib.2014.01.010

Chen, L. C., Chen, Y. H., \& Ma, W. I. (2017). Effects of integrated information literacy on science learning and problem-solving among seventh-grade students. Malaysian Journal of Library \& Information Science, 19(2), 35-51. Retrieved from http://jice.um.edu.my/index.php/MJLIS

Chen, Y. H., \& Chengalur-Smith, I. (2015). Factors influencing students' use of a library Web portal: Applying course-integrated information literacy instruction as an intervention. The Internet and Higher Education, 26, 42-55. doi:10.1016/j.iheduc.2015.04.005

Cordes, S. (2014). Student perceptions of search tool usability. Internet Reference Services Quarterly, 19(1), 3-32. doi:10.1080/10875301.2014.894955

Davis, F. D. (1989). Perceived usefulness, perceived ease of use, and user acceptance of information technology. MIS Quarterly, 13(3), 319-340. doi:10.2307/249008 Retrieved from the author's ResearchGate profile: http://researchgate.net/profile/Fred_Davis2

Davis, F. D., Bagozzi, R. P., \& Warshaw, P. R. (1989). User acceptance of computer technology: A comparison of two theoretical models. Management Science, 35(8), 982-1003. doi:10.1287/mnsc.35.8.982 Retrieved from F. D. Davis's ResearchGate profile: http://researchgate.net/profile/Fred_Davis2

Davis, F. D., \& Venkatesh, V. (2004). Toward preprototype user acceptance testing of new information systems: Implications for software project management. IEEE Transactions on Engineering Management, 51(1), 31-46. doi:10.1109/TEM.2003.822468 Retrieved from F. D. Davis's ResearchGate profile: http://researchgate.net/profile/Fred_Davis2

De Grave, W. S., Boshuizen, H. P. A., \& Schmidt, H. G. (1996). Problem based learning: Cognitive and metacognitive processes during problem analysis. Instructional Science, 24(5), 321-341. doi:10.1007/BF00118111 Retrieved from RePub repository: http://repub.eur.nl

DeLone, W. H., \& McLean, E. R. (2003). The DeLone and McLean model of information systems success: A ten-year update. Journal of Management Information Systems, 19(4), 9-30. doi:10.1080/07421222.2003.11045748 Retrieved from CiteSeerX: http://citeseerx.ist.psu.edu

Eisenberg, M. B. (2008). Information literacy: Essential skills for the information age. DESIDOC Journal of Library \& Information Technology, 28(2), 39-47. doi:10.14429/djlit.28.2.166 Retrieved from the author's ResearchGate profile: http://researchgate.net/profile/Michael_Eisenberg2

Eisenberg, M. B., \& Berkowitz, R. E. (1990). Information problem solving: The Big Six Skills approach to library \& information skills instruction. Norwood, US: Ablex. 
Eisenberg, M. B., \& Berkowitz, R. E. (2007, May). Big6 basics webinar [Slideshow]. Retrieved from M. B. Eisenberg's website: http://faculty.washington.edu/mbe

Eisenberg, M. B., \& Berkowitz, R. E. (2011). The Big6 workshop handbook: Implementation and impact (4th ed.). Santa Barbara, US: ABC-CLIO, LLC.

Eisenberg, M. B., \& Johnson. D. (2002). Learning and teaching information technology computer skills in context (ERIC Document No. ED465377). Retrieved from ERIC: http://eric.ed.gov

Field, A. (2013). Discovering statistics using IBM SPSS statistics. Washington, US: Sage.

Foo, S., Majid, S., Azura Mokhtar, I., Zhang, X., Chang, Y. K., Luyt, B., \& Theng, Y. L. (2014). Information literacy skills of secondary school students in Singapore. Aslib Journal of Information Management, 66(1), 54-76. Retrieved from S. Foo's website: http://ntu.edu.sg/home/sfoo

Georgas, H. (2013). Google vs. the library: Student preferences and perceptions when doing research using Google and a federated search tool. portal: Libraries and the Academy, 13(2), 165-185. doi:10.1353/pla.2013.0011 Retrieved from CUNY Academics Works repository: http://academicworks.cuny.edu

Gross, M., Armstrong, B., \& Latham, D. (2012). The Analyze, Search, Evaluate (ASE) process model: Three steps toward information literacy. Community \& Junior College Libraries, 18(3-4), 103-118. doi:10.1080/02763915.2012.780488

John, S. P. (2013). Influence of computer self-efficacy on information technology adoption. International Journal of Information Technology, 19(1), 1-13. Retrieved from http://intjit.org

Keshavarz, H., Esmaeili Givi, M., \& Vafaeian, A. (2016). Students' sense of self-efficacy in searching information from the Web: A PLS approach. Webology, 13(2), 16-31. Retrieved from http://webology.org

Kuhlthau, C. (2004). Seeking meaning: A process approach to library and information services (2nd ed.) Westport, US: Libraries Unlimited.

Kurbanoglu, S. S., Akkoyunlu, B., \& Umay, A. (2006). Developing the information literacy selfefficacy scale. Journal of Documentation, 62(6), 730-743. doi:10.1108/00220410610714949 Retrieved from S. S. Kurbanoglu's ResearchGate profile: http://researchgate.net/profile/Serap_Kurbanoglu

Lavidas, K., Komis, V., \& Gialamas, V. (2013). Spreadsheets as cognitive tools: A study of the impact of spreadsheets on problem solving of math story problems. Education and Information Technologies, 18(1), 113-129. doi:10.1007/s10639-011-9174-8

Lavidas, K., Komis, V., \& Voulgari, I. (2017). Detecting errors during the construction of mathematical formulas in a spreadsheet environment: An empirical study involving novice users. SCIREA Journal of Education, 2(1), 1-17. Retrieved from http://scirea.org/journal/Education 
Malliari, A., Togia, A., Korobili, S., \& Nitsos, I. (2017). Information literacy skills of Greek high-school students: Results of an empirical survey. Qualitative and Quantitative Methods in Libraries, 3(1), 271-281. Retrieved from http://qqml-journal.net

Mawby, J., Foster, A., \& Ellis, D. (2015). Everyday life information seeking behaviour in relation to the environment: Disposable information? Library Review, 64(6-7), 468-479. doi:10.1108/LR-10-2014-0120 Retrieved from Aberystwyth Research Portal: http://pure.aber.ac.uk/portal

Morrison, R. (2015). Silver surfers search for gold: A study into the online informationseeking skills of those over fifty. Ageing International, 40(3), 300-310. doi:10.1007/s12126-015-9224-4 Retrieved from the author's ResearchGate profile: http://researchgate.net/profile/Renee_Morrison5

Murray, J. (updated 2015, October). Applying Big6 ${ }^{\mathrm{TM}}$ skills, AASL standards and ISTE standards to Internet research. Retrieved November 21, 2019 from the author's website: http://janetsinfo.com

Notess, G. R. (2006). Teaching Web search skills: Techniques and strategies of top trainers. Medford, US: Information Today.

Ntoulas, A., Stamou, S., Tzagarakis, M., \& Christodoulakis, D. (2001). Understanding search engines: Requirements for explaining search results. In N. Avouris \& N. Fakotakis (Eds.), Proceedings of the 1st Panhellenic Conference with International Participation in Human Computer Interaction (PCHCI). Retrieved from M. Tzagarakis's ResearchGate profile: http://researchgate.net/profile/Manolis_Tzagarakis

Parissis, M., Tselios, N., \& Komis, V. (2010). Is searching self efficacy related to search performance? A study of University students' Web information searching strategies. In D. Benzie, K.-W. Lai, \& C. Reffay (Eds), Proceedings of IFIP Working Conferencence New Developments in ICT and Education. Retrieved from Academia.edu: http://academia.edu

Pilgrim, J., \& Martinez, E. E. (2013). Defining literacy in the 21st century: A guide to terminology and skills. Texas Journal of Literacy Education, 1(1), 60-69. Retrieved from ERIC: http://eric.ed.gov

Rose, J., \& Fogarty, G. J. (2006). Determinants of perceived usefulness and perceived ease of use in the technology acceptance model: Senior consumers' adoption of self-service banking technologies. In G. Ogunmokun, R. Gabbay, \& J. Rose (Eds.), Proceedings of the 2nd Biennial Conference of the Academy of World Business, Marketing and Management Development: Business Across Borders in the 21st Century (Vol. 2, pp. 122-129). Retrieved from USQ ePrints repository: http://eprints.usq.edu.au

Salehi, S., Du, J. T., \& Ashman, H. (2018). Use of Web search engines and personalisation in information searching for educational purposes. Information Research: An International Electronic Journal, 23(2). Retrieved from http://informationr.net/ir 
Santana Arroyo, S. (2013). Information literacy for health professionals: Teaching essential information skills with the Big6 information literacy model. Community \& Junior College Libraries, 19(3-4), 77-91. doi:10.1080/02763915.2014.953435 Retrieved from the author's ResearchGate profile: http://researchgate.net/profile/Sonia_Santana_Arroyo

Seddon, P. B. (1997). A respecification and extension of the DeLone and McLean model of IS success. Information Systems Research, 8(3), 240-253. doi:10.1287/isre.8.3.240

Sterling, G. (2017, February 9). Data: Google monthly search volume dwarfs rivals because of mobile advantage. Search Engine Land. Retrieved from http://searchengineland.com

Surendran, P. (2012). Technology acceptance model: A survey of literature. International Journal of Business and Social Research, 2(4), 175-178. https://doi.org/10.18533/ijbsr.v2i4.161

Thomas, N. P., Crow, S. R., \& Franklin, L. L. (2011). Information literacy and information skills instruction: Applying research to practice in the 21st century school library. Santa Barbara, US: Libraries Unlimited.

Van Dinther, M., Dochy, F., \& Segers, M. (2011). Factors affecting students' self-efficacy in higher education. Educational Research Review, 6(2), 95-108. doi:10.1016/j.edurev.2010.10.003

Venkatesh, V., \& Bala, H. (2008). Technology acceptance model 3 and a research agenda on interventions. Decision Sciences, 39(2), 273-315. doi:10.1111/j.1540-5915.2008.00192.x Retrieved from V. Venkatesh's website: http://vvenkatesh.com

Walraven, A., Brand-Gruwel, S., \& Boshuizen, H. P. A. (2008). Information problem-solving: A review of problems students encounter and instructional solutions. Computers in Human Behavior, 24(3), 623-648. doi:10.1016/j.chb.2007.01.030 Preprint retrieved from CORE repository: http://core.ac.uk

Wilson, T. D. (1997). Information behaviour: An interdisciplinary perspective. Information Processing \& Management, 33(4), 551-572. doi:10.1016/S03064573(97)00028-9 Retrieved from the author's ResearchGate profile: http://researchgate.net/profile/Tom_Wilson25

Wopereis, I., Brand-Gruwel, S., \& Vermetten, Y. (2008). The effect of embedded instruction on solving information problems. Computers in Human Behavior, 24(3), 738-752. doi:10.1016/j.chb.2007.01.024 Preprint retrieved from CORE repository: http://core.ac.uk 


\section{Appendix - Survey}

Dear Student,

The following survey is part of a research study with subject: Information seeking on the Web. It is anonymous, so please answer the following questions as honestly as possible. We would be very grateful to receive your responses to the survey, which should take approximately 10-15 minutes to fill out.

\section{PART A: Demographic Information}

Please circle the right answer, or fill in the requested information.

\section{Age:}

Year of study in the Department of Educational Sciences and Early Childhood Education of the Second/Third/Fourth/Year of graduation University of Patras:

Do you have any other undergraduate degree? Yes/No

If yes, from which department(s)?

Do you have a master's degree? Yes/No/ln progress

Do you have a computer at home? Yes/No

Do you have Internet access at home? Yes/No

How many times per week do you use the computer? Daily/3-4 times per week/2-3 times per week/none

How many hours per day are you use the computer? $0-1$ hour/1-2 hours/2 hours and more

How many hours per day do you use the Internet? $\quad 0-1$ hour/1-2 hours/2 hours and more

How long have you been using the Internet? $\quad 0-6$ months/6-12 months/1-2 years/2-3 years/3-4 years/5-......years 


\section{PART B: Perceived Ease of Use of Search Engines}

Below are statements about the ease of use of search engines. Please choose the statement that most applies to you ( 1 = very unlikely; 7 = very likely).

\begin{tabular}{|c|c|c|c|c|c|c|c|c|}
\hline $\begin{array}{l}\text { Item } \\
\text { Code }\end{array}$ & Perceived ease of use & $\begin{array}{c}\text { Very } \\
\text { unlikely } \\
1\end{array}$ & $\begin{array}{c}\text { Unlikely } \\
2\end{array}$ & $\begin{array}{c}\text { Somewhat } \\
\text { unlikely } \\
3\end{array}$ & $\begin{array}{l}\text { Un- } \\
\text { decided } \\
4\end{array}$ & $\begin{array}{l}\text { Somewhat } \\
\text { likely } \\
5\end{array}$ & $\begin{array}{l}\text { Likely } \\
6\end{array}$ & $\begin{array}{l}\text { Very } \\
\text { likely } \\
7\end{array}$ \\
\hline PEOU1 & $\begin{array}{l}\text { Learning to use search } \\
\text { engines is easy for me. }\end{array}$ & $\begin{array}{c}\text { Very } \\
\text { unlikely } \\
1\end{array}$ & 2 & 3 & 4 & 5 & 6 & $\begin{array}{l}\text { Very } \\
\text { likely } \\
7\end{array}$ \\
\hline PEOU2 & $\begin{array}{l}\text { I find search engines to be } \\
\text { flexible to interact with. }\end{array}$ & $\begin{array}{c}\text { Very } \\
\text { unlikely } \\
1\end{array}$ & 2 & 3 & 4 & 5 & 6 & $\begin{array}{l}\text { Very } \\
\text { likely } \\
7\end{array}$ \\
\hline PEOU3 & $\begin{array}{l}\text { I find it easy to get search } \\
\text { engines to do what I want } \\
\text { to do. }\end{array}$ & $\begin{array}{c}\text { Very } \\
\text { unlikely } \\
1\end{array}$ & 2 & 3 & 4 & 5 & 6 & $\begin{array}{l}\text { Very } \\
\text { likely } \\
7\end{array}$ \\
\hline PEOU4 & $\begin{array}{l}\text { It is easy for me to become } \\
\text { skilful at using search } \\
\text { engines. }\end{array}$ & $\begin{array}{c}\text { Very } \\
\text { unlikely } \\
1\end{array}$ & 2 & 3 & 4 & 5 & 6 & $\begin{array}{l}\text { Very } \\
\text { likely } \\
7\end{array}$ \\
\hline PEOU5 & $\begin{array}{l}\text { I find search engines easy } \\
\text { to use. }\end{array}$ & $\begin{array}{c}\text { Very } \\
\text { unlikely } \\
1\end{array}$ & 2 & 3 & 4 & 5 & 6 & $\begin{array}{l}\text { Very } \\
\text { likely } \\
7\end{array}$ \\
\hline PEOU6 & $\begin{array}{l}\text { My interaction with search } \\
\text { engines is clear and } \\
\text { understandable. }\end{array}$ & $\begin{array}{c}\text { Very } \\
\text { unlikely } \\
1\end{array}$ & 2 & 3 & 4 & 5 & 6 & $\begin{array}{l}\text { Very } \\
\text { likely } \\
7\end{array}$ \\
\hline
\end{tabular}

\section{PART C: Perceived Usefulness of Search Engines}

Below are statements about usefulness of search engines. Please choose the statement that most applies to you ( 1 = very unlikely; 7 = Very likely).

\begin{tabular}{|c|c|c|c|c|c|c|c|c|}
\hline $\begin{array}{l}\text { Item } \\
\text { Code }\end{array}$ & Perceived usefulness & $\begin{array}{c}\text { Very } \\
\text { unlikely } \\
1\end{array}$ & $\begin{array}{c}\text { Unlikely } \\
2\end{array}$ & $\begin{array}{c}\text { Somewhat } \\
\text { unlikely } \\
3\end{array}$ & $\begin{array}{l}\text { Un- } \\
\text { decided } \\
4\end{array}$ & $\begin{array}{l}\text { Somewhat } \\
\text { likely } \\
5\end{array}$ & $\begin{array}{l}\text { Likely } \\
6\end{array}$ & $\begin{array}{c}\text { Very } \\
\text { likely } \\
7\end{array}$ \\
\hline PU1 & $\begin{array}{l}\text { Using search engines in my job } \\
\text { would increase my productivity. }\end{array}$ & $\begin{array}{c}\text { Very } \\
\text { unlikely } \\
1\end{array}$ & 2 & 3 & 4 & 5 & 6 & $\begin{array}{l}\text { Very } \\
\text { likely } \\
7\end{array}$ \\
\hline PU2 & $\begin{array}{l}\text { Using search engines in my job } \\
\text { would enable me to accomplish } \\
\text { tasks more quickly. }\end{array}$ & $\begin{array}{c}\text { Very } \\
\text { unlikely } \\
1\end{array}$ & 2 & 3 & 4 & 5 & 6 & $\begin{array}{l}\text { Very } \\
\text { likely } \\
7\end{array}$ \\
\hline PU3 & $\begin{array}{l}\text { I find search engines useful in my } \\
\text { job. }\end{array}$ & $\begin{array}{c}\text { Very } \\
\text { unlikely } \\
1\end{array}$ & 2 & 3 & 4 & 5 & 6 & $\begin{array}{l}\text { Very } \\
\text { likely } \\
7\end{array}$ \\
\hline PU4 & $\begin{array}{l}\text { Using search engines would } \\
\text { enhance my effectiveness on the } \\
\text { job. }\end{array}$ & $\begin{array}{c}\text { Very } \\
\text { unlikely } \\
1\end{array}$ & 2 & 3 & 4 & 5 & 6 & $\begin{array}{l}\text { Very } \\
\text { likely } \\
7\end{array}$ \\
\hline PU5 & $\begin{array}{l}\text { Using search engines would } \\
\text { improve my job performance. }\end{array}$ & $\begin{array}{c}\text { Very } \\
\text { unlikely } \\
1\end{array}$ & 2 & 3 & 4 & 5 & 6 & $\begin{array}{l}\text { Very } \\
\text { likely } \\
7\end{array}$ \\
\hline PU6 & $\begin{array}{l}\text { Using search engines would } \\
\text { make it easier to do my job. }\end{array}$ & $\begin{array}{c}\text { Very } \\
\text { unlikely } \\
1\end{array}$ & 2 & 3 & 4 & 5 & 6 & $\begin{array}{l}\text { Very } \\
\text { likely } \\
7\end{array}$ \\
\hline
\end{tabular}

\section{PART D: Self-Efficacy towards the Use of Search Engines}

Please indicate how capable you feel you are in performing Google's advanced search strategies, when searching for information on the Web. There are no "right" or "wrong" answers; the best answer is the immediate, spontaneous one. I feel I am capable of....: 


\begin{tabular}{|c|c|c|c|c|c|c|c|c|}
\hline $\begin{array}{l}\text { Item } \\
\text { Code }\end{array}$ & $\begin{array}{l}\text { Advanced Google } \\
\text { search strategies }\end{array}$ & $\begin{array}{l}\text { Not at all } \\
\text { capable } \\
1\end{array}$ & $\begin{array}{c}\text { Not so } \\
\text { capable } \\
2\end{array}$ & $\begin{array}{c}\text { A little } \\
\text { capable } \\
3\end{array}$ & $\begin{array}{c}\text { Somewhat } \\
\text { capable } \\
4\end{array}$ & $\begin{array}{l}\text { Fairly } \\
\text { capable } \\
5\end{array}$ & $\begin{array}{c}\text { Very } \\
\text { capable } \\
6\end{array}$ & $\begin{array}{c}\text { Totally } \\
\text { capable } \\
7\end{array}$ \\
\hline 1 & Finding an exact phrase & $\begin{array}{c}\text { Not at all } \\
\text { capable } \\
1\end{array}$ & 2 & 3 & 4 & 5 & 6 & $\begin{array}{c}\text { Totally } \\
\text { capable } \\
7\end{array}$ \\
\hline 2 & Searching within a website & $\begin{array}{c}\text { Not at all } \\
\text { capable } \\
1\end{array}$ & 2 & 3 & 4 & 5 & 6 & $\begin{array}{c}\text { Totally } \\
\text { capable } \\
7\end{array}$ \\
\hline 3 & Excluding words & $\begin{array}{c}\text { Not at all } \\
\text { capable } \\
1\end{array}$ & 2 & 3 & 4 & 5 & 6 & $\begin{array}{c}\text { Totally } \\
\text { capable } \\
7\end{array}$ \\
\hline 4 & $\begin{array}{l}\text { Using the wildcard asterisk (*) to } \\
\text { create searches where there are } \\
\text { unknown characters, multiple } \\
\text { spellings or various endings }\end{array}$ & $\begin{array}{c}\text { Not at all } \\
\text { capable } \\
1\end{array}$ & 2 & 3 & 4 & 5 & 6 & $\begin{array}{c}\text { Totally } \\
\text { capable } \\
7\end{array}$ \\
\hline 5 & $\begin{array}{l}\text { Exacting match search on a single } \\
\text { word }\end{array}$ & $\begin{array}{c}\text { Not at all } \\
\text { capable } \\
1\end{array}$ & 2 & 3 & 4 & 5 & 6 & $\begin{array}{c}\text { Totally } \\
\text { capable } \\
7\end{array}$ \\
\hline 6 & $\begin{array}{l}\text { Searching for any one of one or more } \\
\text { terms to match -OR operator }\end{array}$ & $\begin{array}{l}\text { Not at all } \\
\text { capable } \\
1\end{array}$ & 2 & 3 & 4 & 5 & 6 & $\begin{array}{c}\text { Totally } \\
\text { capable } \\
7\end{array}$ \\
\hline 7 & $\begin{array}{l}\text { Defining the number of search results } \\
\text { on page }\end{array}$ & $\begin{array}{c}\text { Not at all } \\
\text { capable } \\
1\end{array}$ & 2 & 3 & 4 & 5 & 6 & $\begin{array}{c}\text { Totally } \\
\text { capable } \\
7\end{array}$ \\
\hline 8 & $\begin{array}{l}\text { Defining the language of the search } \\
\text { results displayed }\end{array}$ & $\begin{array}{c}\text { Not at all } \\
\text { capable } \\
1\end{array}$ & 2 & 3 & 4 & 5 & 6 & $\begin{array}{c}\text { Totally } \\
\text { capable } \\
7\end{array}$ \\
\hline 9 & $\begin{array}{l}\text { Choosing the file type you want to } \\
\text { search }\end{array}$ & $\begin{array}{c}\text { Not at all } \\
\text { capable } \\
1\end{array}$ & 2 & 3 & 4 & 5 & 6 & $\begin{array}{c}\text { Totally } \\
\text { capable } \\
7\end{array}$ \\
\hline 10 & $\begin{array}{l}\text { Defining the date/time of last update } \\
\text { of the websites displayed }\end{array}$ & $\begin{array}{c}\text { Not at all } \\
\text { capable } \\
1\end{array}$ & 2 & 3 & 4 & 5 & 6 & $\begin{array}{c}\text { Totally } \\
\text { capable } \\
7\end{array}$ \\
\hline 11 & Searching within a specific domain & $\begin{array}{c}\text { Not at all } \\
\text { capable } \\
1\end{array}$ & 2 & 3 & 4 & 5 & 6 & $\begin{array}{c}\text { Totally } \\
\text { capable } \\
7\end{array}$ \\
\hline 12 & $\begin{array}{l}\text { Defining where the term will appear in } \\
\text { the webpage-like title or URL }\end{array}$ & $\begin{array}{c}\text { Not at all } \\
\text { capable } \\
1\end{array}$ & 2 & 3 & 4 & 5 & 6 & $\begin{array}{c}\text { Totally } \\
\text { capable } \\
7\end{array}$ \\
\hline 13 & $\begin{array}{l}\text { Defining the geographical location of } \\
\text { the search results }\end{array}$ & $\begin{array}{c}\text { Not at all } \\
\text { capable } \\
1\end{array}$ & 2 & 3 & 4 & 5 & 6 & $\begin{array}{c}\text { Totally } \\
\text { capable } \\
7\end{array}$ \\
\hline 14 & Searching for a range of numbers & $\begin{array}{c}\text { Not at all } \\
\text { capable } \\
1\end{array}$ & 2 & 3 & 4 & 5 & 6 & $\begin{array}{c}\text { Totally } \\
\text { capable } \\
7\end{array}$ \\
\hline 15 & Activating the safe search filter & $\begin{array}{c}\text { Not at all } \\
\text { capable } \\
1\end{array}$ & 2 & 3 & 4 & 5 & 6 & $\begin{array}{c}\text { Totally } \\
\text { capable } \\
7\end{array}$ \\
\hline 16 & $\begin{array}{l}\text { Finding pages with similar content to } \\
\text { a site given }\end{array}$ & $\begin{array}{c}\text { Not at all } \\
\text { capable } \\
1\end{array}$ & 2 & 3 & 4 & 5 & 6 & $\begin{array}{c}\text { Totally } \\
\text { capable } \\
7\end{array}$ \\
\hline 17 & $\begin{array}{l}\text { Finding search results that contain } \\
\text { hyperlinks to website given }\end{array}$ & $\begin{array}{c}\text { Not at all } \\
\text { capable } \\
1\end{array}$ & 2 & 3 & 4 & 5 & 6 & $\begin{array}{c}\text { Totally } \\
\text { capable } \\
7\end{array}$ \\
\hline
\end{tabular}

